\title{
PENGARUH PEMBERIAN RANSUM KOMBINASI SUPLEMEN HERBAL DENGAN MINERAL ZINK TERHADAP JUMLAH LEUKOSIT, ERITROSIT, DAN KADAR HEMOGLOBIN BROILER YANG DIINFEKSI ESCHERICHIA COLI
}

\author{
M.N.Regar ${ }^{1}$, R. Mutia $^{2}$, S.D.Widhyari ${ }^{3}$, Y.H.S.Kowel ${ }^{1}$ \\ ${ }^{1}$ Fakultas Peternakan Universitas Sam Ratulangi Manado \\ ${ }^{2}$ Fakultas Peternakan Institut Pertanian Bogor \\ ${ }^{3}$ Fakultas Kedokteran Hewan Institut Pertanian Bogor
}

\begin{abstract}
ABSTRAK
Penelitian ini dilakukan untuk menguji pengaruh pemberian kombinasi herbal dengan mineral zink dalam ransum broiler yang diinfeksi Escherichia coli (E. coli) terhadap kinerja kesehatan broiler. Dua ratus ekor d.o.c (day old chick) dibagi secara acak ke dalam lima perlakuan, masing-masing perlakuan diulang empat kali sehingga terdapat 20 unit percobaan, setiap unit percobaan terdiri dari 5 ekor d.o.c. Anak ayam percobaan dipelihara selama 35 hari. Ransum perlakuan terdiri dari $\mathrm{R} 1$ = Pakan basal/ ayam sehat (kontrol negatif); R2 = Pakan basal/ ayam diinfeksi E.coli (kontrol positif); R3= Pakan basal + serbuk kunyit $1.5 \%+\mathrm{ZnO} 180 \mathrm{ppm} /$ ayam diinfeksi E.coli; R4 = Pakan basal + serbuk bawang putih $2.5 \%+\mathrm{ZnO} 180 \mathrm{ppm} /$ ayam diinfeksi E.coli; R5 = Pakan basal + antibiotik/ ayam diinfeksi E.coli. Penelitian menggunakan rancangan acak lengkap. Peubah yang diamati jumlah leukosit, eritrosit, dan kadar hemoglobin. Hasil dari penelitian ini menunjukkan bahwa pemberian kombinasi kunyit $1.5 \%$ dengan $\mathrm{ZnO} 180$ ppm dan kombinasi bawang putih $2.5 \%$ dengan $\mathrm{ZnO}$ 180 ppm dalam ransum mampu
\end{abstract}

memperlihatkan kinerja kesehatan yang lebih baik.

Kata Kunci: Suplemen herbal, mineral zink, tampilan broiler.

\section{ABSTRACT}

EFFECT OF COMBINATION BETWEEN HERBAL SUPPLEMENT AND ZINC MINERALS IN RATION ON TOTAL OF LEUCOCYT, ERYTHROCYTE, AND HEMOGLOBIN LEVEL IN BROILERS INFECTED BY ESCHERICHIA COLI. This experiment was conducted to study the combination of herbal material and zink in poultry diet on the leucocyte, erythrocyte and hemoglobin of broilers infected by the amount of Escherichia coli. Two hundred of unsexed d.o.c broilers were devided into five treatments and four replications in each treatment, with five chicks in each replicate. The treatments were basal diet as a negative control/ healhty chickens (R1), basal diet as a positive control, chick was infected by Escherichia coli (R2), basal diet + $1.5 \%$ turmeric powder $+\mathrm{ZnO} 180 \mathrm{ppm}$, chick was infected by Escherichia coli (R3), basal diet $+2.5 \%$ garlic powder $+\mathrm{ZnO} 180 \mathrm{ppm}$, 
chick was infected by Escherichia coli (R4), and basal diet + antibiotic, chick was infected by Escherichia coli (R5). Data were collected during 35 days. Diet and water were offered ad libitum. The results of this research indicated that chicken fed basal diet $+1.5 \%$ turmeric powder $+\mathrm{ZnO} 180 \mathrm{ppm}$, chick was infected by Escherichia coli (R3) and chickens fed basal diet $+2.5 \%$ garlic powder $+\mathrm{ZnO} 180$ ppm chick was infected by Escherichia coli (R4) showed the best leucocyte, erythrocyte and hemoglobin amount compared with control.

Key words: Herbal supplement, zinc mineral, broiler performance.

\section{PENDAHULUAN}

Industri perunggasan merupakan salah satu industri yang cukup penting dalam penyediaan protein hewani dan merupakan sumber pendapatan bagi masyarakat. Pencegahan dan pengendalian penyakit adalah salah satu kendala dalam industri perunggasan. Daya tahan tubuh ternak sangat penting peranannya dalam menangkal berbagai macam penyakit. Daya tahan erat kaitannya dengan sistem kekebalan tubuh yang ditunjang oleh fungsi sel imun serta produksi antibodi. Sistem pertahanan yang semakin baik, sistem imun tubuh semakin tangguh melawan berbagai agen infeksi. Pakan merupakan salah satu faktor yang berperan dalam peningkatan daya tahan tubuh ternak. Kecukupan zink ( $\mathrm{Zn})$ dalam pakan diduga berperan dalam peningkatan daya tahan tubuh. Menurut Zinc information (2008) zink sangat esensial dalam mengatur sel normal sebagai media fungsi sistem imun tubuh.

Upaya pencegahan penyakit yang telah dilakukan selain penggunaan zink dalam ransum yaitu dengan pemberian antibiotik. Penggunaan antibiotik dalam pakan ternak bertujuan sebagai pemacu pertumbuhan, untuk memperbaiki efisiensi penggunaan pakan dan pencegahan terhadap kemungkinan infeksi patogen (Solomon, 1978). Antibiotik dipercaya dapat menekan pertumbuhan bakteribakteri patogen yang berakibat melambungnya populasi bakteri menguntungkan dalam saluran pencernaan. Tingginya mikroflora menguntungkan tersebut dapat merangsang terbentuknya senyawa-senyawa antimikrobial, asam lemak bebas dan zat-zat asam sehingga terciptanya lingkungan kurang nyaman bagi pertumbuhan bakteri patogen (Samadi, 2004).

Penggunaan antibiotik ini mulai memberikan masalah yang serius yaitu ditemukannya residu antibiotik dalam karkas ternak yang akhirnya meningkatkan prevalensi kasus penyakit infeksi yang 
resistan terhadap antibiotik pada manusia (Revington, 2002). Residu antibiotik akan terbawa dalam produk-produk ternak seperti daging, telur, dan susu, dan akan berbahaya bagi konsumen yang mengkonsumsinya. Rusiana dalam Samadi (2004) melaporkan dari 80 ekor broiler di Jabodetabek $85 \%$ daging broiler dan $37 \%$ hati ayam tercemar residu antibiotik tylosin, penisilin, oxytetracycline dan kanamycin.

Berbagai alternatif mulai dikembangkan untuk mencari alternatif bahan pakan tambahan yang lebih aman, antara lain melalui penggunaan enzim, probiotik, prebiotik, asam-asam organik, rempah-rempah dan ekstrak tanaman obat (Wenk, 2000). Penggunaan herbal dalam pakan menjadi salah satu alternatif untuk mengatasi masalah tersebut, yaitu dengan menggunakan herbal kunyit dan bawang putih. Penggunaan herbal kunyit dan bawang putih secara tunggal telah banyak dilakukan, namun penggunaan dengan mengkombinasikan kedua herbal tersebut ditambah mineral zink belum ada penelitian yang melaporkan.

Kunyit dimanfaatkan untuk menambah cerah atau warna kuning kemerahan pada kuning telur, jika dicampurkan pada ransum ayam, dapat menghilangkan bau kotoran ayam dan menambah berat badan ayam, juga minyak atsiri kunyit bersifat antimikroba (Winarto,
2003). Pemberian kunyit pada taraf $0.6 \%$ dalam ransum broiler memberikan hasil terbaik pada performa broiler yaitu mampu meningkatkan konsumsi ransum dan pertambahan bobot badan broiler (Agustina, 1996). Hardian (2004), penambahan tepung kunyit dalam ransum berpengaruh sangat nyata terhadap pertambahan bobot badan mencit umur 35 hari dengan penambahan tepung kunyit 4 $\%$.

Komponen aktif dalam bawang putih, allicin merupakan zat aktif yang mempunyai daya bunuh pada bakteri dan anti radang; alliin merupakan suatu asam amino antibiotik dan menurunkan kolesterol darah dan daging broiler (Jaya, 1997). Wiryawan et al. (2005) menggunakan metode pembubukan bawang putih dengan dosis $2.5 \%$ dalam mengatasi serangan Salmonella typhimurium pada ayam pedaging. Bubuk bawang putih sebanyak $2.5 \%$ dalam ransum dapat menurunkan koloni bakteri Salmonella typhimurium. Agustina (2003), penggunaan ekstrak bawang putih dengan konsentrasi $2.5 \%$ dapat menanggulangi kecacingan pada ayam petelur. Suharti (2004) melaporkan pemberian serbuk bawang putih $2.5 \%$ dalam ransum dapat meningkatkan konversi ransum, meningkatkan persentase karkas, serta menurunkan koloni bakteri Salmonella typhimurium. Mineral zink dalam bentuk 
zink inorganik mempunyai fungsi meningkatkan performans dan respon imun terhadap broiler (Ali et al. 2003).

Berdasarkan latar belakang di atas maka dilakukan penelitian tentang penggunaan kombinasi kunyit, bawang putih dengan zink dalam pakan broiler terhadap performa. Selanjutnya, dalam penelitian ini tantangan Escherichia coli (E. coli) diperlukan untuk mengetahui seberapa jauh kemampuan pemberian kombinasi herbal-Zn mampu menekan munculnya kasus kolibasilosis, serta kemampuannya dalam menanggulangi kejadian kolibasilosis yang merupakan salah satu penyakit bersifat fatal dan menyebabkan kematian cukup tinggi.

\section{MATERI DAN METODE PENELITIAN}

Ayam percobaan yang digunakan berumur sehari sebanyak 200 ekor strain Hybro produksi PT Manggis Farm. Ransum kontrol yang digunakan terdiri dari jagung, dedak, minyak kelapa, tepung ikan, bungkil kedelai, $\mathrm{CaCO}_{3}, \mathrm{DCP}$, premiks, lysin dan methionin. Ransum di buat dalam bentuk crumble. Kandungan protein ransum $24.62 \%$ dan GE 3842 $\mathrm{kkal} / \mathrm{kg}$ untuk periode starter dan kandungan protein ransum $19.80 \%$ dan GE $4086 \mathrm{kkal} / \mathrm{kg}$ untuk periode grower.
Ayam dibagi secara acak ke dalam lima perlakuan, masing-masing perlakuan diulang empat kali sehingga terdapat 20 unit percobaan, setiap unit percobaan terdiri dari 10 ekor d.o.c. Anak ayam percobaan dipelihara selama 35 hari. Ransum perlakuan terdiri dari $\mathrm{R} 1=$ Pakan basal/ ayam sehat (kontrol negatif); R2 = Pakan basal/ ayam diinfeksi E.coli (kontrol positif); R3= Pakan basal + serbuk kunyit $1.5 \%+\mathrm{ZnO} 180 \mathrm{ppm} /$ ayam diinfeksi E. coli $; \mathrm{R} 4$ = Pakan basal + serbuk bawang putih $2.5 \%+\mathrm{ZnO} 180 \mathrm{ppm} /$ ayam diinfeksi E.coli; R5 = Pakan basal + antibiotik/ ayam diinfeksi E.coli.

Pada umur 3 minggu dilakukan infeksi E.coli dosis $10^{8} \mathrm{CFU} / \mathrm{ml}$, pengambilan sampel darah dilakukan sebelum dan sesudah infeksi dilakukan yaitu pada umur 3 minggu dan 5 minggu. Antibiotik merk Colimas ${ }^{\circledR}$ dengan dosis pengobatan diberikan 1 hari setelah infeksi selama 3 hari, diberikan dalam air minum.

Peubah yang diamati adalah kinerja kesehatan yang dinilai berdasarkan jumlah eritrosit, leukosit, dan kadar haemoglobin. Rancangan percobaan yang digunakan adalah Rancangan Acak Lengkap (RAL). Data yang diperoleh dianalisis sidik ragam (SPSS versi 17.0) dan apabila ada perbedaan dilanjutkan dengan uji Beda Nyata Terkecil (Steel dan Torrie, 1995). 


\section{HASIL DAN PEMBAHASAN}

Hasil penelitian terhadap kinerja kesehatan (jumlah leukosit, eritrosit, dan kadar hemoglobin) disajikan pada Tabel 1. Hasil analisis statistik terhadap jumlah leukosit sebelum infeksi $E$. coli tidak menunjukkan perbedaan antar perlakuan. Sesudah infeksi E. coli kadar leukosit nyata $(\mathrm{P}<0.05)$ dipengaruhi penambahan kombinasi kunyit, bawang putih dengan zink. Nilai leukosit menunjukkan peningkatan setelah infeksi $E$. coli. Hal ini disebabkan adanya respon kekebalan tubuh terhadap E. coli sebagai benda asing, yang kemudian ditindaklanjuti dengan melepaskan sejumlah sel leukosit menuju jaringan yang diserang. Jumlah leukosit tertinggi pada perlakuan $\mathrm{R} 4$ diduga terjadi karena adanya peran allicin dalam bawang putih yang berfungsi sebagai antibakteri untuk mencegah adanya infeksi sekunder (Rabinowitch dan Currah, 2002).

Tabel 1. Jumlah leukosit, eritrosit, dan kadar hemaglobin ayam pedaging sebelum dan sesudah infeksi E. coli

\begin{tabular}{|c|c|c|c|c|c|c|}
\hline \multirow[t]{2}{*}{ Perlakuan } & \multicolumn{2}{|c|}{$\begin{array}{l}\text { Leukosit } \\
\left(\mathrm{sel} / \mathrm{mm}^{3}\right)\end{array}$} & \multicolumn{2}{|c|}{$\begin{array}{c}\text { Eritrosit } \\
\left(10^{6} / \mathrm{mm}\right)\end{array}$} & \multicolumn{2}{|c|}{$\begin{array}{c}\text { Hemoglobin } \\
(\mathrm{g} \%)\end{array}$} \\
\hline & Sebelum & Sesudah & Sebelum & Sesudah & Sebelum & Sesudah \\
\hline \multirow[t]{2}{*}{$\mathrm{R} 1$} & 11550 & $8700^{\mathrm{a}}$ & 2.27 & 2.26 & $7.40^{\mathrm{a}}$ & $8.25^{\mathrm{a}}$ \\
\hline & \pm 4225 & \pm 4241 & \pm 0.09 & \pm 0.90 & \pm 0.33 & \pm 1.02 \\
\hline \multirow[t]{2}{*}{$\mathrm{R} 2$} & 14000 & $17500^{\mathrm{b}}$ & 2.36 & 2.10 & $8.10^{\mathrm{ab}}$ & $6.70^{b}$ \\
\hline & \pm 1780 & \pm 3493 & \pm 0.59 & \pm 0.48 & \pm 0.62 & \pm 0.74 \\
\hline \multirow[t]{2}{*}{ R3 } & 13650 & $15650^{\mathrm{ab}}$ & 2.67 & 2.64 & $8.53^{\mathrm{bc}}$ & $8.05^{\mathrm{a}}$ \\
\hline & \pm 1408 & \pm 7620 & \pm 0.27 & \pm 0.49 & \pm 0.34 & \pm 0.41 \\
\hline \multirow[t]{2}{*}{$\mathrm{R} 4$} & 11925 & $17600^{\mathrm{b}}$ & 2.53 & 2.31 & $7.65^{\mathrm{a}}$ & $7.05^{\mathrm{a}}$ \\
\hline & \pm 2941 & \pm 6965 & \pm 0.08 & \pm 0.67 & \pm 0.41 & \pm 1.24 \\
\hline \multirow[t]{2}{*}{ R5 } & 11450 & $16350^{\mathrm{ab}}$ & 2.66 & 2.57 & $8.00^{\mathrm{ac}}$ & $7.05^{\mathrm{a}}$ \\
\hline & \pm 5082 & \pm 6945 & \pm 0.18 & \pm 0.40 & \pm 0.59 & \pm 1.08 \\
\hline
\end{tabular}

Keterangan : $\quad$ Huruf yang berbeda dalam kolom yang sama menunjukkan perbedaan yang nyata $(\mathrm{p}<0.05)$. Sebelum : ayam berumur 1- 3 minggu belum diinfeksi E. coli

Sesudah : ayam berumur 3-5 minggu telah diinfeksi $E$. coli

R1(ransum basal/ kontrol negatif), R2 (ransum basal/ kontrol positif), R3 (ransum basal + serbuk kunyit 1.5\%/ infeksi E. coli), R4 (ransum basal + serbuk bawang putih 2.5\%/ infeksi E. coli), R5 (ransum basal + antibiotik/ infeksi E. coli). 
Hasil analisis statistik untuk jumlah eritrosit ayam pedaging sebelum dan sesudah infeksi E. coli tidak menunjukkan perbedaan antar perlakuan. Jumlah eritrosit tertinggi pada perlakuan kombinasi kunyit dengan zink diduga karena eritrosit mampu bertahan lebih lama dalam sirkulasi dengan adanya zink dan kunyit yang mengandung kurkumin memberikan efek antioksidan terhadap membran sel. Jain (1993) mengatakan masa hidup eritrosit unggas lebih pendek dari mamalia yaitu rata-rata kurang dari 50 hari. Kerusakan bentuk dari membran eritrosit dapat mempengaruhi masa hidup eritrosit. Gropper et al. (2005), Zn memberikan efek langsung terhadap konformasi protein membran dan/ atau interaksi antar protein pada membran sel. Peranan $\mathrm{Zn}$ sebagai antioksidan, berfungsi membuang radikal bebas pada plasma membran. Zn mempengaruhi aktivitas sejumlah enzim yang melekat pada membran sel, Klasing (1999) menjelaskan bahwa Zn merupakan aktivator atau kofaktor lebih dari 200 enzim.

Hasil analisis statistik sebelum infeksi E. coli terhadap kadar hemoglobin nyata $(\mathrm{P}<0.05)$ dipengaruhi penambahan kombinasi kunyit dengan zink. Tingginya kadar hemoglobin diduga disebabkan oleh adanya kurkumin yang terkandung dalam kunyit yang berfungsi sebagai antioksidan yang dapat melindungi hemoglobin dari oksidasi. Reaksi oksidatif dapat merusak hemoglobin (Meyer dan Harvey 2004). Hemoglobin sangat penting untuk kelangsungan hidup karena membawa dan mengantarkan $\mathrm{O}_{2}$ ke jaringan (Jain 1993). Sesudah infeksi E. coli, analisis statistik menunjukkan kadar hemoglobin perlakuan R2 nyata lebih rendah dibanding perlakuan R1, R3, R4 dan R5. Tingginya kadar hemoglobin pada R1 disebabkan perlakuan ini tidak mendapat infeksi E. coli, kadar hemoglobin menurun bila terjadi infeksi.

\section{KESIMPULAN}

Pemberian kombinasi kunyit $1.5 \%$ dengan $\mathrm{ZnO} 180$ ppm dan kombinasi bawang putih 2.5\% dengan $\mathrm{ZnO} 180$ ppm dalam ransum mampu memperlihatkan status kesehatan yang lebih baik.

\section{DAFTAR PUSTAKA}

Agustina A. 1996. Penggunaan tepung kunyit (Curcuma domestica) dalam ransum terhadap penampilan dan daya tahan tubuh ayam pedaging [skripsi]. Bogor: Fakultas Peternakan, Institut Pertanian Bogor.

Agustina. 2003. Atasi infeksi cacing dengan bawang putih. Infovet No.111:44-45. 
Ali SA, Sayed MAM, El-wafa SA, Abdallah AG. 2003. Performance and immune response of broiler chick as affected by methionine and zinc or commercial zinkmethionine supplementations [abstrak]. Di dalam : J Egypt Poult Sci; Egypt : Animal Production Research Insitute, ARC, Dokki. hlm 523-540. Abstr vol.23 no.3.

Gropper SS, Smith JL, Groff JL. 2005. Advanced Nutrition and Human Matabolism. Ed ke-4. USA: Wardsworth.

Hardian S. 2004. Performa hasil silangan mencit agouti dan mencit putih pada penambahan tepung kunyit (Curcuma domestica, Val.) dalam ransum [skripsi]. Bogor: Fakultas Peternakan, Institut Pertanian Bogor.

Jain NC. 1993. Essential of Veterinary Hematology. Philadelphia: Lea \& Febiger.

Jaya INS. 1997. Pengaruh penambahan bawang putih (Allium sativum L.) dalam pakan pada kadar kolesterol ayam broiler [tesis]. Bogor: Program Pascasarjana, Institut Pertanian Bogor.

Klasing KC. 2000. Comparative Avian Nutrition. London: CAB International.

Meyer DJ, Harver JW. 2004. Veterinary Laboratory Madicine Interpretation and Diagnosis. $3^{\text {rd }}$ Edition. USA: Saunders.

Rabinowitch HD, Currah L. 2002. Alium Crop Science: Recent Advances. New York : CABI Publishing.

Revington B. 2002. Feeding Poultry in The Post-Antibiotics Era. Onario : New-Life Mills Limited. 1400 Bishop Street. Suite 201. Cambridge.
Samadi. 2004. Feed quality for food savety kapankah indonesia?. Inovasi Vol.2/XVI.

Solomon IA. 1978. Antibiotics in Animal feeds-human and animal safety issues. J Anim Sci 46:1360-1368.

Steel RGD, Torrie JH. 1995. Prinsip dan Prosedur Statistika. Suatu Pendekatan Biometrik. Edisi ke-2. Sumantri B, penerjemah; Jakarta : Gramedia Pustaka Utama.

Suharti S. 2004. Kajian antibakteri temulawak, jahe dan bawang putih terhadap bakteri Salmonella thphimurium serta pengaruh bawang putih terhadap performans dan respon imun ayam pedaging [tesis]. Bogor: Program Pascasarjana, Institut Pertanian Bogor.

Wenk C. 2000. Hebs, species and botanicals: "old fashioned" or the new feed additives for tomorrows feed formulation?. concepts for their successful use. Di dalam : Biotechnology in Feed Industry. Proceedings of Alltech's $16^{\text {th }}$. Annual Symposium, hlm 79-96.

Winarto WP. 2003. Khasiat dan Manfaat Kunyit. Cetakan ke-1. Jakarta : Agromedia Pustaka.

Wiryawan KG, Suharti S, Bintang M. 2005. Kajian antibakteri temulawak, jahe, dan bawang putih terhadap Salmonella typhimurium serta pengaruh bawang putih terhadap performans dan respon imun ayam pedaging. Media Peternakan 28(2): 52-62.

Zink information. 2008. Zinc. http://www.mindat.orgmin29191.html [Mar 2008]. 